\title{
Depresszió és az erőszak kapcsolata a serdülőkorúak és a fiatal felnőttek körében: három külföldi hosszmetszeti kohorsz vizsgálat eredményei
}

\author{
Depression and Violence in Adolescence and Young Adults: Findings \\ From Three Longitudinal Cohorts
}

Ismertető: Járomi Éva $\bowtie$

Országos Közegészségügyi Intézet

Beküldve: 2017.09.13.

doi: 10.24365/ef.v58i3.187

Kulcsszavak: depresszió, erőszak, serdülók és fiatal felnőttek, longitudinális, születési kohorsz

Keywords: depression, violence, adolescences and young adults, longitudinal study, birth cohort

\section{BEVEZETŐ}

A depresszió világszerte az egyik leggyakoribb megbetegedés, amely több mint 300 millió embert érint. Különbözik a szokásos kedélyváltozástól és a mindennapi életre adott érzelmi reakcióktól. Súlyos egészség-problémává válhat, ha hosszú ideig tart és nagy intenzitással jelentkezik. A depresszió kialakulásában közrejátszó kockázati tényezők lehetnek, ha az érintett személy érzelmileg nagymértékben szenved vagy elégedetlen például a munkahelyével, az iskolával, és/vagy a családban. A depresszió a társas, pszichológiai és biológiai tényezők összetett kölcsönhatásából ered, és azoknál az embereknél nagyobb valószínüséggel alakul ki, akik nehéz életeseményeken mentek keresztül (pl. munkanélküliség, gyász, lelki trauma). ${ }^{1}$

Az elmúlt időszak empirikus kutatásai nemzetközi szinten azt mutatják, hogy a depresszióban szenvedő egyének körében az erőszak kockázata igen magas. A depresszió és az erőszak közötti kapcsolat a felnőttek esetében a longitudinális kohorsz-vizsgálatok mellett keresztmetszeti vizsgálatokban és regiszter-alapú kutatásokban volt megfigyelhető. Különösen igaz ez a legutóbbi teljes svéd populációt felölelő longitudinális vizsgálat eredményeire, ahol a depresszióban szenvedő egyének körében háromszor nagyobb volt az erőszakos büncselekmények elkövetésének kockázata, mint a normál populációban. $^{2}$

Jelen közlemény célja a fiatalkori depresszió és a későbbi erőszakos viselkedés közötti hosszmetszeti összefüggések bemutatása. ${ }^{3}$

A depresszió-erőszak kapcsolatára irányuló eddigi kutatások szerint az említett két tényező közötti összefüggés erősebb lehet a serdülőknél, mint a felnőtteknél, mivel a serdülőkori depresszió összehasonlítva annak felnőttkori változatával, nagyobb valószínűséggel társul türelmetlenséggel és ingerlékenységgel, amely tulajdonságok szintén összefüggnek az erőszakos viselkedéssel.

Korábbi kutatások a depresszió-erőszak kapcsolatát olyan klinikai mintákon elemezték, amelyekben a depressziót dichotóm változóként vizsgálták. ${ }^{4,5}$ Azonban annak megállapítása, hogy ez a kapcsolat klinikai körülményeken kívül is fennáll-e, további kutatásokat igényel. Mindez azért különösen fontos, mert a serdülőkorban jelentkező enyhébb 
depressziós tünetek előrejelzik a felnőttkori előrehaladott depressziós zavarok kialakulását és a későbbi problémás viselkedést is. A serdülők csoportjából képzett, nagymintán végzett depresszió és erőszak közötti kapcsolat kutatása, melyek körében mind az enyhébb depressziós tünetek, mind az erőszakos viselkedések dominálnak, a jelenlegi bizonytalanságok feloldását szolgálják.

A fogvatartó és a büntetés-végrehajtási intézmények is nagyarányú depresszióról számoltak be a serdülők körében (a fiúk 11\%-ánál, míg a lányok estében 29\%-ra becsülték az előfordulási arányt). Mivel a depresszió erőszakkal vagy azzal összefüggő rendellenességekkel társulhat, ún. magatartászavarral, valamint olyan további tényezőkkel, mint a genetikai hajlam vagy a kortárs viktimizáció, javasolt hosszútávú kutatásokkal vizsgálni a depresszió és a későbbi erőszakos viselkedés közötti összefüggést a zavaró tényezőkre történő folytonos korrigálás mellett.

Bár a különböző kutatások összefüggést mutatnak az erőszak és a depresszió között a felnőttek körében, ez a kapcsolódás a serdülők esetében meglehetősen bizonytalan. Az ismertetett vizsgálat éppen ennek a bizonytalanságnak a feloldására tesz kísérletet a longitudinális összefüggések felmérésével, a depresszió és a későbbi erőszakos kimenetelek közötti kutatással a fiatalok körében.

\section{A VIZSGÁLAT ALKALMAZOTT MÓDSZERE}

A depresszió-erőszak kapcsolatának vizsgálatára többszörös mintavételezési megközelítést alkalmaztak. A tanulmányban szereplő három kohorsz vizsgálatban a különböző depressziónak való kitettséget és a későbbi erőszakos kimenetet nézték. Egy holland kohorsz kutatásban a serdülők (13-17 évesek) fejlődéséről és kapcsolatairól (Research on Adolescent Development And Relationships, röviden RADAR, $N=623)^{6}$, valamint egy népességalapú szülők és gyermekek bevonásával történt brit longitudinális születési kohorsz vizsgálatban (Avon Longitudinal Study of Parents and Children, röviden ALSPAC, $N=4030$ ) a serdülókori depressziós tünetek és az erőszakos viselkedés hosszmetszeti kapcsolódását elemezték a 13-17 évesek körében. ${ }^{7}$ Egy teljes körű finn, 1987-től kutatott születési kohorsz vizsgálatban (Finnish birth cohort, röviden FBC 1987, N = 57 526) pedig az erőszakos búncselekmények elkövetésének kockázatát nézték kontrollcsoportos vizsgálattal klinikailag diagnosztizált depreszszióban szenvedő egyéneknél 15 és 27 év között. ${ }^{8}$

A fent említett három kutatás több olyan pozitív tulajdonsággal rendelkezik, amely miatt alkalmassá váltak a vizsgálatban való részvételre. A kohorszok mindegyike jó minőségú longitudinális adatokat tartalmazott a depresszióról és az erőszakról a fiatalok körében, egy kisléptékű közösségi mintából egy teljes születési kohorszra vonatkoztatva. Mind a három kohorsz a vizsgált változók komplementer intézkedéseit alkalmazta, beleértve a depresszió önértékelését és a klinikai diagnózisait, valamint az erőszakos viselkedések önértékelési/kérdezőbiztos által történő jelentését valamint az erőszakos búncselekmények hivatalos nyilvántartását. Az elemzett változók jellemzői és a kiegészítő mérések lehetőséget nyújtottak arra, hogy a korábbiaknál átfogóbb módon vizsgálják meg a depresszió és az erőszak közötti kapcsolatot.

\section{ESZKÖZÖK}

Depressziós tünetek és diagnózis:

A RADAR és az ALSPAC kohorszban a depressziós tünetek értékelése kérdőívvel történt. A RADAR-ban a Reynolds Serdülőkori Depresszió Skálával (Reynolds's Adolescent Depression Scale, 2nd RADS-2) mértek, amely egy 23 kérdésből álló önkitöltős kérdőív (pl. "Úgy érzem, már semmi sem segít többé"). Az ALSPAC kohorszban a depressziós tüneteket az SMFQ (Mood and Feelings Kérdőív Mood and Feelings Questionnaire) rövid változatával mérték meg, amely az elmúlt 2 hétben tapasztalt tüneteknek egy 13 tételes ellenőrzőlistája (pl. "Az elmúlt 2 hétben érezte-e magát szomorúnak vagy boldogtalannak?"). A serdülők 13 éves korukban egy hárompontos skálában jelölték depressziós tüneteiket: 1 (igaz), 2 (néha igaz) és 3 (nem igaz).

Az FBC esetében a klinikai diagnózisról szóló információkat az Országos Egészségügyi és Jóléti Intézet (National Institute for Health and Welfare, továbbiakban THL) által fenntartott finn Kórházi Zárójelentési Nyilvántartásból (Hospital Discharge Register, továbbiakban HDR) gyújtötte. A HDR az 
epidemiológiai kutatások valid és megbízható eszköze. A nyilvántartás egészen 1998-tól tartalmazza az állami kórházak összes speciális fekvő- és járóbeteg látogatását.

\section{Erőszakos viselkedés és elítélés:}

A RADAR és az ALSPAC kohorszokban az elmúlt 12 hónapban az erőszakos viselkedéseket kérdőívekkel mérték.

A RADAR-ban az International Self-Report Delinquency Study-n alapuló skálát használták.

Az erőszakos viselkedések közé tartozott a fenyegető vagy erőszakos személy általi lopás, támadás, valakinek a fegyverrel történő bántalmazása, bántalmazás (ütés, rúgás). Azok a serdülők, akik a felsorolt erőszakos magatartások közül legalább egyet elkövettek (14-17 éves korig), erőszakosnak minősültek.

Az ALSPAC-ban mind a serdülők, mind az édesanyjuk a serdülők erőszakos viselkedéséról számoltak be egy bizalmas, önkitöltős kérdőívben, amelyet eredetileg az Edinburgh kutatás, az Ifjúsági Átmenetről és Bünözésről (Edinburgh Study of Youth Transitions and Crime) fejlesztett ki.

\section{Statisztikai elemzések:}

A depresszió és a későbbi erőszak esélyhányadosának (EH) kiszámításához logisztikus regresszió elemzéseket végeztek Mplus statisztikai programmal, melyben függő, azaz kimeneteli változó volt az elkövetett erőszakos magatartás és meggyőződés, míg a depressziós tünetek és diagnózis magyarázó, azaz független változóként jelent meg. A fiúk és lányok között megfigyelhető különbséget, a depresszió és az erőszakos kimenetelek közötti kapcsolat vizsgálatát, alcsoportelemzéssel végezték. A családi szocioökonómiai státuszt és a korábbi erőszak hatásait mindhárom kohorszban figyelembe vették a zavaró tényezők korrigálásánál.

\section{EREDMÉNYEK}

A vizsgálatok alapján összefüggés mutatkozik a depresszió és az azt követő erőszakos viselkedésmódok, valamint a család szocio-ökonómiai státusza és a korábbi erőszakos viselkedések között.
Az átlagos utánkövetési periódus 4 éve alatt az erőszakos viselkedések egységnyi növekedésének korrigált esélyhányadosa depressziós tünetek esetében a holland RADAR mintában 1,7 volt $(95 \% \mathrm{Cl}=1,2-$ 2,5), a brit ALSPAC születési kohorszban $1,8\left(95 \% \mathrm{Cl}^{i}\right.$ $=1,4-2,3)$.

Az FBC 1987-es kohorszában, az erőszakos viselkedések esélyhányadosa $2,1(95 \% \mathrm{Cl}=1,7-2,7)$ volt a depresszióval diagnosztizált egyének körében, öszszehasonlítva a kontrollcsoporttal (általános depresszióban nem szenvedő populációval). Minden kockázati becslést a családi szocio-ökonómiai státusszal és a korábbi erőszakkal korrigálták.

\section{KONKLÚZIÓ}

A három longitudinális tanulmány egymással egybehangzó megállapításai azt mutatják, hogy a klinikai irányelveknek fontolóra kellene vennie a depresszióban szenvedő fiatalok kockázatértékelését. Emellett a nemek szerinti alcsoportok célzott kockázatkezelésének hasznosságáról további vizsgálatokra van szükség.

A serdülők és a fiatal felnőttek kohorszában, mindhárom longitudinális analízisben, a későbbi erőszakos viselkedés kockázata nőtt (EH: 1,7-2,1 között). Azt is megállapították, hogy az erőszakos kimenetelek esélye általában magasabb volt a lányoknál $(\mathrm{EH}$ : 2,2 és 7,1 között), mint a fiúknál (EH: 1,6- 2,7 között). Ugyanakkor a lányok abszolút kockázata a három kohorszban lényegesen alacsonyabb volt. A fentiekkel kapcsolatos korábbi kutatások azt mutatják, hogy a depresszió aránya - amely az erőszakos viselkedés kockázatát növeli -, magas a serdülőkorúaknál a fogvatartó-, illetve a javító-nevelő intézményekben.

A három kutatás elemzését tartalmazó vizsgálat korlátja, hogy csupán három viszonylag magas jövedelmú országból származó adatokat vizsgált. A serdülőkori depressziós zavarok prevalenciája a három kohorszban összehasonlítható volt a világ összevont prevalenciájával, azonban a fiatalkori erőszak aránya nemzetenként jelentősen eltér: a magas jövedelmú országokban alacsonyabb, mint az alacsony és közepes jövedelmú országokban. Ezért az

Konfidencia intervallum 
alacsony és közepes jövedelmű országokban a depresszió és az erőszak kapcsolatának jövőbeli vizsgálata kiemelkedően fontos lenne. További korlát volt, hogy különböző eszközöket használtak a depresszióra és az erőszakra vonatkozó adatok összegyűjtésére. Bár a három minta esélyhányadosa jól összehasonlítható, azokat eltérő módon kell értelmezni. Ezenkívül a kohorszokon belüli különböző módszerek eredményeinek közvetlen összehasonlítása nem volt lehetséges. A tanulmányok különböző mérései továbbá a minták heterogenitásához vezettek.

A jövőbeli vizsgálatok során több adatra van szükség a mérések validitásának növelése érdekében. Bár jelen tanulmány bizonyítékot szolgáltat arra nézve, hogy a depresszió képes előrejelezni a jövőbeni erőszakos cselekményeket, fennáll annak a lehetősége is, hogy a depresszió és az erőszak egymást erősítik, így növelve hatásukat egymástól függetlenül és együttesen is az idő múlásával.

Az a megállapítás, mely szerint a serdülők és a fiatal felnőttek depressziója hosszú távú erőszakos kimenetelekkel is járhat, fontos lehet a beavatkozások és a megelőzések fejlesztése szempontjából. Bár az öngyilkossági kockázatértékelés a klinikai gyakorlat részét képezi a depresszióban szenvedő egyéneknél, az erőszak kockázatának megállapítását nagymértékben elhanyagolják. Az Egyesült Államok klinikai gyakorlatára vonatkozó irányelvei nagyon röviden kitérnek erre az összefüggésre, az Egyesült Királyság Egészségügyi és Ellátási Kiválóságok Intézetének (NICE) irányelvei között ez nem jelenik meg. ${ }^{9}$

Összességében a kutatások arra engednek következtetni, hogy a depresszió időben történő kezelése valószínúleg csökkenti az erőszakos magatartás kialakulásának későbbi kockázatát, ily módon a depresszió korai azonosítása és kezelése széles körű népegészségügyi előnyökkel járhat.

A fenti megállapítások hangsúlyozzák a depresszió- ban szenvedő egyének kockázatkezelésének potenciális jelentőségét a törvényszéki környezetben, beleértve a fiatalkorúak fogvatartási és a büntetés-végrehajtási formáit is.

Mivel az erőszakos viselkedés esélye magasabb a lányoknál, a jövőbeli kutatásokban nagyobb hangsúlyt kellene fektetni a depresszióval küzdő lányok kockázatelemzésére és kezelésére.

A három különböző, viszonylag magas jövedelmú országban készült kutatás eredményei alapján elmondható, hogy az erőszak emelkedett kockázata tapasztalható fokozott depressziós tünetekkel társulva a serdülők és fiatal felnőttek, valamint a klinikailag igazolt depresszióban szenvedők körében, továbbá a genetikai meghatározottság és a stresszérzékenység közvetítheti a depresszió és az erőszak közötti kapcsolatot egyéni szinten.

Az eredmények rámutatnak arra, hogy a fiatalkori depresszió kezelésének fejlesztésére, a folyamatok/eljárásrendek tisztázására, valamint - amennyiben tovább validálják - a klinikai irányelvek felülvizsgálatára van szükség.

Hazánkban sajnos nem állnak rendelkezésre hasonló összefüggés-vizsgálatok ebben a témában, így különösen nagy jelentősége lehet az e témájú kutatások módszertani tanulmányozásának, a hazai kutatásokba történő adaptálhatóságának tekintetében.

Hazánkban a mentális betegségek egyre növekvő prevalenciája következtében kialakuló egyéni és társadalmi terhek vizsgálatára irányuló kutatások mellett, korszerú, interdiszciplináris módon múködő prevenciós ellátási rendszer kiépítésére van szükség. ${ }^{10}$ Ennek keretében kiemelkedően fontos a mentális zavarral küzdők stigmatizációjának csökkentése, illetve a korai felismerés és kezelésbe irányítás, mely települési, járási, regionális valamint egyéni és közösségi szinten egyaránt hosszútávon fenntartható beavatkozásokat igényel. 


\section{HIVATKOZÁSOK}

\footnotetext{
${ }^{1}$ http://www.who.int/mediacentre/factsheets/fs369/en/ (Elérve: 2017.09.22.)

2 Fazel S, Wolf A, Chang Z, Larsson H, Goodwin GM, Lichtenstein P. Depression and violence: a Swedish population study. Lancet Psychiatry. 2015;2:224-232

${ }^{3}$ Rongqin Yu, PhD, et al Depression and Violence in Adolescence and Young Adults: Findings From Three Longitudinal Cohorts Journal Of The American Academy Of Child \& Adolescent Psychiatry, Volume 56 Number 8 August 2017. ${ }^{4}$ Stringaris A, Maughan B, Copeland WS, Costello EJ, Angold A. Irritable mood as a symptom of depression in youth: prevalence, developmental, and clinical correlates in the Great Smoky Mountains Study. J Am Acad Child Adolesc Psychiatry. 2013;52:831-840

${ }^{5}$ Fazel S, Wolf A, Chang Z, Larsson H, Goodwin GM, Lichtenstein P. Depression and violence: a Swedish population study. Lancet Psychiatry. 2015;2:224-232.

${ }^{6}$ https://www.uu.nl/onderzoek/radar (Elérve: 2017.09.22.)

7 Jean Golding and the ALSPAC Study Team The Avon Longitudinal Study of Parents and Children (ALSPAC) - study design and collaborative opportunities European Journal of Endocrinology (2004) 151 U119-U123

8 Paananen R, Gissler M. Cohort profile: the 1987 Finnish Birth Cohort. Int J Epidemiol. 2012;41:941-945

${ }^{9}$ National Institute for Health and Care Excellence. Depression in children and young people: identification and management clinical guideline [CG28]. 2015. https://www.nice.org.uk/guidance/cg28/resources/depression-in-children-andyoung-people-identification-and-management-pdf-975332810437 (Elérve: 2017. 09.25)

${ }^{10}$ Kopp M.: Nemzeti Lelki Egészség Stratégia 2014-2020. 2014. január
} 